\title{
ARCANGELIELLA, GYMNOMYCES, AND MACOWANITES IN NORTH AMERICA
}

SANFORD M. ZELLER

Visiting Fellow in the Henry Shaw School of Botany of Washington University AND CARROLL W. DODGE

Formerly Rufus J. Lackland Fellow in the Henry Shaw School of Botany of Washington University

\section{ARCANGELIELLA}

Arcangeliella Cavara, Nuov. Giorn. Bot. Ital. N. S. 7: 117128. 1900 ; Saccardo \& Sydow in Sacc. Syll. Fung. 16: 255256. 1902.

The type species of the genus is Arcangeliella Borziana Cavara.

Fructifications gregarious, hypogaeous or emergent, fleshy, lactiferous; peridium thin, separable with difficulty, extending to the base in young specimens but evanescent and disappearing below at maturity; columella simple or branched, often extending to the peridium above; base more or less sterile, usually attenuated and leading to rhizomorphs, generally lactiferous; gleba fragile, lactiferous; cavities minute, irregular, radiating more or less from the columella and base; basidia 2-4-spored; cystidia present; spores globose to ellipsoidal, echinulate to verrucose, tinted.

This is a distinct genus which is closely related to $\mathrm{Maco}$ wanites Kalchbr. The description has been emended here to include some variation in characters which evidently Cavara did not have the opportunity to observe in the type species and which are necessary to include Arcangeliella caudata and A. Soderstromii.

1. Arcangeliella caudata Zeller \& Dodge, sp. nov.

Fructificationes globosae, base attenuata, superne complanatae aut piriformes, "dilute brunneae vel saturatius vel fusco-rubideae, area subalbida parva inferne prope stipite excepta" (Gardner), "mummybrown" vel "clove-brown" (Ridgway) superne, "clay-color" vel "olive-brown" (Ridgway) inferne servatae, $0.8-2 \mathrm{~cm}$. diametro, 
superficie villosa; peridium 200-300 $\mu$ crassitudine superne tenuissimum vel absens inferne, "sepia" (Ridgway) sub lente, radialibus hyphis septatis, perpendicularibus superficiei fructificationis, pseudoparenchyma faciens cuius cellulae $9-10 \times 11-13 \mu$, septis hypharum constrictis, ex peridio labuntur et globosae vel oblongae, conidiiformes fiunt; basis sterilis attenuata, hyphis hyalinis, septatis, $3-5 \mu$ diametro confecta; ductus lactiferi numerosi ad basim attenuatam, septati, 6-8 $\mu$ crassitudine; rhizomorphi pseudoparenchymate, brunnei, multis ductibus lactiferis muniti; columella variabilis, inconspicua vel percurrens aut ramosa, ab base non distincta, eodemque colore, ductibus lactiferis paucis; gleba carnosa, "Isabellacolor" vel "brownish olive" (Ridgway), inferne aperta maturitate; locelli parvi et irregulares, ex base et columella radiantes; septa hyalina, hyphis hyalinis laxe implexis, ductibus lactiferis paucis, 50-65 $\mu$ crassitudine; cystidia hyalina, magna, clavata; paraphyses cylindrici, obtusi, hyalini, septati, $19-20 \times 4-5 \mu$; basidia hyalina, tenua, clavata, bi- vel tetraspora, 24-26 $\times 9-13 \mu$, sterigmatibus brevibus, 3-6 $\boldsymbol{\mu}$ longitudine; sporae ovatae vel ellipsoideae, uno cum vacuolo magno, pedicellatae, "yellow ocher" vel "ochraceous tawny" (Ridgway), $12-14.5 \times 9-11.5 \mu$, exosporio crasso, verrucoso-rugoso. bri.

Habitat in foliis putridis Quercus agrifoliae. California. Novem-

Type: in Univ. Cal. Herb., Zeller Herb., and Dodge Herb.

Fructifications globose, with attenuate base and flattened or plane above, some quite pyriform, "varying from light brown to a dark yellowish brown or maroon except on a limited area on the under side next to the very short stipe which is almost white" (Gardner), mummy-brown to clovebrown above and clay-color to olive-brown below (in alcohol), $0.8-2 \mathrm{~cm}$. in diameter, surface velvety; peridium 200-300 $\mu$ thick above, very thin or wanting below, sepia under the microscope, composed of radial, septate hyphae perpendicular to the surface, forming pseudoparenchymatous tissue having cells about $9-10 \times 11-13 \mu$, the septa of the hyphae becoming constricted and finally sloughing off globose to oblong conidialike cells from the surface of the peridium; base sterile, composed of septate, hyaline hyphae 3-5 $\mu$ in diameter, with lactiferous ducts more numerous towards the attenuate point which leads to a heavy, branched rhizomorph; lactiferous ducts of base 6-8 $\mu$ broad; rhizomorphs pseudoparenchymatous, brown, supplied with numerous lactiferous ducts; columella variable from inconspicuous to percurrent, extending to the peridium above, sometimes with 
lateral branches, concolorous and continuous with the base, the few lactiferous ducts smaller than in the base; gleba fleshy, Isabella-color to brownish olive, exposed near the base in older specimens; cavities small and irregular, somewhat radiating from the base and columella; septa hyaline, consisting of loosely interwoven, hyaline hyphae, few lactiferous ducts, 50 $65 \mu$ broad; cystidia hyaline, large, clavate; paraphyses cylindrical, obtuse, hyaline, septate, 19$20 \times 4-5 \mu$; basidia hyaline, s l e n d e r, clavate, 2-4s p or ed, $24-26 \times 9-13 \mu$; sterigmata short, stout, 3-6 $\mu$ long; spores mostly ovate to ellipsoid, o n e l a rg e vacuole, exospore thick, verrucose-rugose, pedicellate, yellow ocher to ochraceous-tawny, 12$14.5 \times 9-11.5 \mu$.

In leaf mould of Quercus agrifolia. California. November.

The characters of the spores, columella, and peridium distinguish Arcangeliella caudata from the two other species

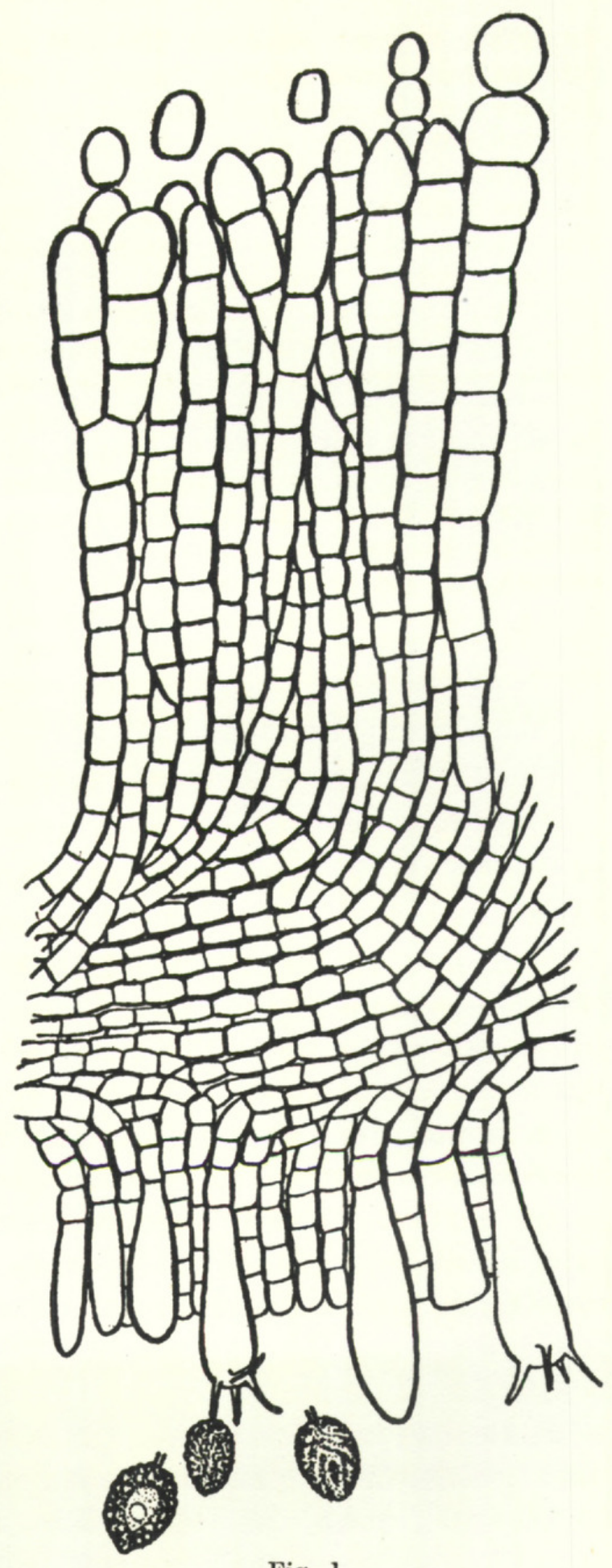

Fig. 1

A. caudata.

Section of peridium and hymenium; spores. $\times 750$. From type. 
of the genus. The peridium is more nearly like that of $A$. Borziana than of $A$. Soderstromii, but it is much thicker than either and has long perpendicular hyphae forming a distinct, pseudoparenchymatous tissue. The conidia-like cells which are given off from the tips of these hyphae may be an unobserved character in A. Borziana, but probably do not occur at all in a species like $A$. Soderstromii where the peridial hyphae extend parallel with the surface. The spores of $A$. caudata are like some Hymenogaster spores and if these only are observed one would naturally put the species in Hymenogaster.

Specimens examined:

California: Berkeley, N. L. Gardner, type (in Univ. Cal. Herb., 219, 219a, 219b, and 219c, Zeller Herb., 1623, and Dodge Herb., 1249).

2. Arcangeliella Soderstromii (Lagerh.) Zeller \& Dodge, comb. nov.

Hydnangium Soderstromii Lagerheim in Patouillard \& Lagerheim, Soc. Myc. Fr. Bul. 9 : 142. 1893; Saccardo, Syll. Fung. $11: 172.1895$.

Illustrations: Patouillard, Soc. Myc. Fr. Bul. $9: p l$. 8. f. 6 , $6 a-c$.

Type: location unknown to us, but a cotype is in the Lloyd Museum.

Fructifications subglobose to pyriform, buckthorn-brown to Isabella-color, $2-3.5 \mathrm{~cm}$. in diameter; sterile base attenuate, short; columella usually percurrent, confluent with the peridium above, slender, unbranched; peridium thin, 50-70 $\mu$ thick, evanescent, ochraceous-tawny, composed of slender, interwoven hyphae, with lactiferous ducts extending parallel with the surface; gleba fragile when dry, chamois to Isabella-color; cavities variable in size, radiating from the base and columella; septa $40-45 \mu$ broad, melleus, stupose, with a few lactiferous ducts; cystidia clavate, often mucronate, 38-40 $\times 8-10 \mu$, hyaline, guttulate; paraphyses truncateclavate, septate, hyaline; basidia subcylindrical, hyaline, guttulate, mostly 2-spored, $40-60 \times 6-10 \mu$; sterigmata stout, 
8-10 $\mu$ long; spores spherical, "honey-colored," echinulate, 11-15 $\mu$ in diameter, seldom pedicellate, exospore about $2 \mu$ thick.

In soil under Eucalyptus. California and Ecuador. Spring and autumn.

Lagerheim states in the original description of Hydnangium Soderstromii that it has no cystidia, but a study of the cotype in the Lloyd Museum reveals both clavate and mucronate forms. The specimen from California has the characteristic cystidia of the Ecuador specimens and a stout, percurrent columella with few lactiferous ducts. The chief distinction between this species and A. Borziana and A. caudata is in the peridial characters.

Specimens examined:

California: Ingleside, San Francisco, N. L. Gardner (Univ. Cal. Herb., 209, in part, and Zeller Herb., 1643).

Ecuador: Quito, Panecillo, G. Lagerheim, cotype (in Lloyd Mus., 6395); L. Mille (in Lloyd Mus., 12127).

\section{EXTRA-LIMITAL SPECIES}

The only reported species of this genus which has not been found in North America is the type of the genus.

1. Arcangeliella Borziana Cavara, Nuov. Giorn. Bot. Ital. N. S. $7: 126$. 1900; Saccardo \& Sydow in Sacc. Syll. Fung. $16: 256.1902$.

Illustrations: Cavara, Nuov. Giorn. Bot. Ital. N. S. 7: $p l$. 7. f. 1-15.

Fructifications hypogaeous, gregarious, globose to irregular, oblong, often bilobed, $0.6-0.8 \times 1.5-2.0 \mathrm{~cm}$. in diameter, light, nearly smooth; peridium very thin, $70 \mu$ thick, fragile, either lacking or lacerate near the base, spotted with yellow, slightly lactiferous; gleba light rose-colored, lactiferous; columella percurrent, very lactiferous; base attenuate, sterile; latex white, sweet, abundant; basidia conspicuous, strongly exerted above the blunt paraphyses; sterigmata $3-4$, acicular, long; spores spheroidal to amply ellipsoidal, dilute yellowish, echinulate, $8-10 \mu$ in diameter; cystidia conical, acute.

In fir forests. Vallombrosa, Etruria, Italy. Summer. 
The original description of Arcangeliella Borziana has been amplified here to include some characters which Cavara gave in his discussion of the species.

\section{GYMNOMYCES}

Gymnomyces Massee \& Rodway, Kew Bul. Misc. Inf. 1898: 125. 1898; Saccardo \& Sydow in Sacc. Syll. Fung. 16: 249. 1902.

Type: Gymnomyces pallidus and G. seminudus were published simultaneously with no reference to type.

Fructifications globose to irregular; peridium delicately downy or silky to evanescent, or entirely wanting; columella very much branched and dendroid when present; gleba fleshy, fertile to the base, lacunose, light-colored; cavities subequal to labyrinthiform; septa not scissile, composed of branched, interwoven, hyaline hyphae; basidia hyaline, cylindrical to clavate, mostly 2 -spored; spores hyaline, globose, echinulate to verrucose.

This genus is similar to Gautieria in that it has no persistent peridium, but is markedly different from Gautieria in the spore characters. Gymnomyces has close affinities with some species of Hydnangium and Octaviania, having very thin peridia, but the spores are hyaline.

1. Gymnomyces Gardneri Zeller \& Dodge, sp. nov.

Fructificationes subglobosae vel irregulares, plerumque superne inferneque complanatae, $2.5 \times 1.5 \times 1.5 \mathrm{~cm}$. diametro servatae, $1.4 \times$ $0.8 \times 0.8 \mathrm{~cm}$. siccatae, "cream-color" vel "yellow ocher" (Ridgway) servatae, "tawny olive" (Ridgway) siccatae; peridium nullum; stipes non visus; columella septa crassissima simulans, dendroidea, glebam quasi in gregibus locellorum indistinctis dividens, hyphis gelatinosis hyalinis composita, "russet brown" (Ridgway) siccata; gleba "cream-color" vel "clay-color" (Ridgway) siccata, ad basim sporifera; locelli parvi, circa $0.5 \mathrm{~mm}$. diametro servati, globosi vel irregulares; septa hyalina, non scissilia, $60-80 \mu$ crassitudine; basidia hyalina, clavata, duobus cum sterigmatibus, $25-29 \times 9-10 \mu$; sterigmata tenua, 6-7 $\boldsymbol{\mu}$ longa; sporae globosae vel oblongae, hyalinae, $6-9.6 \times 10-13 \mu$, verrucosae (reticulato-rugosae cum maxime magnificatae sint). bri.

Habitat in terra sub foliis Quercus agrifoliae. California. Decem-

Type: in Univ. Cal. Herb. and in Zeller Herb. 
Fructifications subglobose to irregular, mostly flattened above and below, $2.5 \times 1.5 \times 1.5 \mathrm{~cm}$. in diameter in alcohol, drying to $1.4 \times 0.8 \times 0.8 \mathrm{~cm}$., cream-color to yellow ocher in alcohol, tawny olive when dry; peridium entirely lacking; no stipe on specimens examined; columella dendroid, resembling much-thickened septa, dividing the gleba into indistinct areas, consisting of quite gelatinous, hyaline hyphae, and drying to a russet brown; gleba cream-color to clay-color when dry, fertile to the base; cavities small, averaging 2 to the $\mathrm{mm}$. in alcohol, globose to irregular; septa hyaline, not scissile, $60-80 \mu$ broad; basidia hyaline, clavate, with 2 sterigmata, $25-29 \times 9-10 \mu$; sterigmata slender, 6-7 $\mu$ long; spores globose to oblong, hyaline, 6-9.6×10-13 $\mu$, verrucose (reticulate-rugose under the oil immersion).

Upon the ground under leaves of

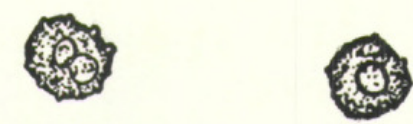

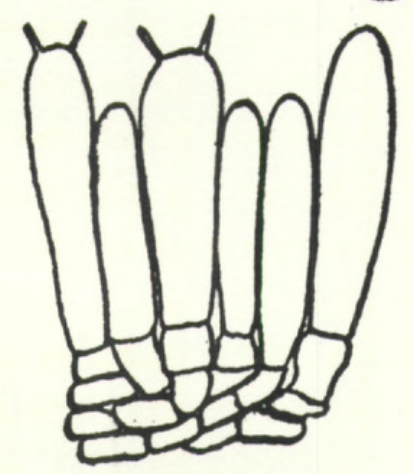

Fig. 2

G. Gardneri. Basidia and spores. $\times 750$. From type. Quercus agrifolia. California. December.

G. Gardneri differs from G. pallidus and G. seminudus in color and spore characters and in that it has a columella. In spore characters it has nearest affinities with G. pallidus.

Specimens examined:

California: Alameda Co., Berkeley, N. L. Gardner, type (in

Univ. Cal. Herb., 376, and in Zeller Herb., 1618).

\section{EXTRA-LIMITAL SPECIES}

We are including the descriptions of the extra-limital species to assist in referring material to them should these be found in North America. The descriptions are translations from the original.

1. Gymnomyces pallidus Massee \& Rodway, Kew Bul. Misc. Inf. 1898 : 125. 1898; Saccardo \& Sydow in Sacc. Syll. Fung. $16: 249$. 1902.

Type: Rodway, 299, in Kew Herb. 
Fructifications irregularly globose, $2-4 \mathrm{~cm}$. in diameter, very fragile; no distinct peridium; gleba at first white, then dirty white; sterile base obsolete, but in one specimen the base growing into a slender stem emerging from an umbilicus; glebal cavities somewhat enlarged, irregular, dirty white; septa narrow, white, not scissile; spores globose, 9-10 $\mu$ in diameter, hyaline, verrucose, often short-caudate, two to each basidium, supported on short sterigmata.

Under ground. Tasmania.

2. Gymnomyces seminudus Massee \& Rodway, Kew Bul. Misc. Inf. 1898 : 125. 1898; Saccardo \& Sydow in Sacc. Syll. Fung. 16 : 249-250. 1902.

Type: Rodway, 124, in Kew Herb.

Fructifications globose, $1.5-2.5 \mathrm{~cm}$. in diameter; peridium when present delicately tomentose; gleba white, fertile to the base; glebal cavities minute, very crowded, empty, irregular; septa somewhat broad, white, not scissile; basidia subclavate; sterigmata two ; spores spherical, 11-12 $\mu$ in diameter, closely echinulate, hyaline.

Emerging from the ground. Tasmania.

Gymnomyces seminudus Mass. \& Rodw. is distinguished from G. pallidus Mass. \& Rodw. by the larger, strongly and densely echinulate spores.

\section{MACOWANITES}

Macowanites Kalchbrenner in Sacc. Syll. Fung. 7:179. 1888; Fischer in Engler \& Prantl, Die Nat. Pflanzenfam. I. $1^{* *}:$ 299-300. f. 148. 1899.-Macowania Kalchbrenner, Gardeners' Chron. N. S. 5:785. f. 141. 1876.-Not Macowania Oliver in Hooker, Icon. Pl. III. 1 : 49. 1870.

The type species of the genus is Macowanites agaricinus Kalchbrenner.

Fructifications subglobose to hemispherical, epigaeous or hypogaeous, stipitate, fleshy; peridium covering the upper surface of the fructification, thin; stipe distinct below, but may or may not reach to the peridium above as a percurrent 
columella; gleba covered above, exposed and decurrent, adnate or sinuous below; cavities globose to irregular; septa homogeneous; basidia 2-spored; spores spheroidal to ovate, hyaline, tuberculate or echinulate.

This genus was first described as Macowania by Kalchbrenner, in 1876, but since this name was preoccupied by Macowania Oliver (1870), DeToni changed the name to Macowanites, retaining Kalchbrenner as the author.

The genus Macowanites Kalchbr. is an extremely close ally to the genus Arcangeliella, differing mainly in the absence of lactiferous ducts. The spores of Arcangeliella are usually ellipsoidal and tinted, while those of Macowanites are spherical and hyaline. This, however, does not hold for Arcangeliella Soderstromii, which has spherical spores.

The fact that the two known species of Macowanites are from such widely separated localities would indicate the probability that this genus is much more widely distributed than at present known.

1. Macowanites echinosporus Zeller \& Dodge, sp. nov.

Fructificationes subglobosae vel irregulares, $1 \times 1.5 \mathrm{~cm}$. diametro, laeves, subtiliter "salmon-colored" (Gardner) recens lectae, "tawny olive" (Ridgway) servatae; peridium tenue, $90-120 \mu$ crassitudine, in dimidio superiore fructificationis instructum, hyalina, pseudoparenchymate parallela cum superficie fructificationis confectum; stipes eodem colore, $5 \mathrm{~mm}$. longitudine, $2 \mathrm{~mm}$. diametro, stuposus, tenuibus hyphis hyalinis contextus; basis sterilis, proiectura conica stipitis, sed non ut columella in glebam proiciens; gleba superne tecta, inferne aperta, non decurrens sed circum stipitem sinuata, eodem colore ut peridium; locelli minuti, irregulares; septa $60-80 \mu$ crassitudine, hyalina, pseudoparenchymate confecta, non scissilia; cystidia infrequentia, clavata, apiculata, $9-10 \times 20-24 \mu$, hyalina; basidia parva, $5-8 \times 18-22 \mu$, cylindrata vel clavata, bi- vel tetraspora, hyalina; sporae sphaeroideae vel late ovatae, hyalinae, appendiculatae, 6-8 $\mu$ diametro, uno cum vacuolo, minute sparsimque echinulatae.

Habitat in terra sub Quercu agrifolia. California. Mart.

Type: in Univ. Cal. Herb. and Zeller Herb.

Fructifications subglobose to irregular, $1 \times 1.5 \mathrm{~cm}$. in diameter, even, smooth, very delicate salmon-color (Gardner), in alcohol tawny olive; peridium thin, $90-120 \mu$ thick, extending over the upper half of the fructification, consisting of a 
hyaline pseudoparenchyma extending parallel with the surface; stipe concolorous, about $5 \mathrm{~mm}$. long and 2 $\mathrm{mm}$. in diameter, stupose, of fine hyaline hyphae; sterile base a conical projection of the stipe extending into the gleba but not percurrent; gleba covered above, exposed below, not

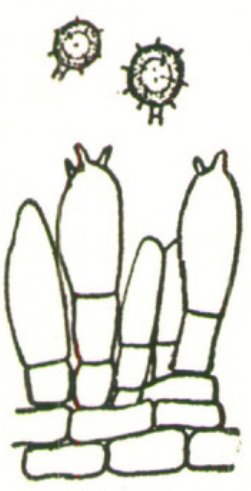

Fig. 3

M. echinosporus. Basidia and spores. $\times 625$. From type. decurrent but sinuate about the stipe, concolorous with the peridium; cavities minute, irregular; septa 60-80 $\mu$ broad (including hymenia), hyaline, composed of pseudoparenchymatous cells, not scissile; cystidia rarely present, clavate, apiculate, $9-10 \times 20-24 \mu$, hyaline; basidia small, 5-8 $\times 18-22 \mu$, cylindrical to clavate, 2-4-spored, hyaline; spores spherical to broadly ovate, hyaline, appendaged, 6-8 $\mu$ in diameter, one large vacuole, finely and sparingly echinulate.

Hypogaeous under Quercus agrifolia. California. March.

Macowanites echinosporus is distinct from M. agaricinus in spore characters, color of the fructifications, relation of gleba to stipe, and in that the columella does not extend to the peridium above. The generic description has been emended to include these characters.

Specimen examined:

California: East Oakland, N.L. Gardner, type (in Univ. Cal. Herb., 402, and Zeller Herb., 1624).

\section{EXTRA-LIMITAL SPECIES}

The type species of this hitherto monotypic genus has not been found in North America, but the original description is appended for taxonomic convenience.

1. Macowanites agaricinus Kalchbrenner in Sacc. Syll. Fung. $7: 179.1888$.

Macowania agaricina Kalchbr. in Gardeners' Chron. N. S. $5: 785.1876$.

Illustrations: Kalchbrenner, Gardeners' Chron. N. S. 5 : 785. f. 141; Fischer in Engler \& Prantl, Die Nat. Pflanzenfam. I. $1^{* * *}: f .148$. 
Type: probably at Kew. Fragment in N. Y. Bot. Gard. Herb.

"Peridium hemispherical, even above, dingy, of a dirty brown, produced below into a short stem-like, smooth, white process, which penetrates up to the apex of the peridium, and is surrounded above by the large cells of the hymenium, which are below much elongated and project beyond the peridium, their apertures open to the air and decurrent. Odour strong, like that of Garlic; spores rather large, globose; epispore thick, slightly tuberculate."

-Kalchbrenner.

Habitat: among Acacia thickets. East Somerset, South Africa.

In this work we have used as a standard for color descriptions Ridgway, 'Color Standards and Nomenclature,' Washington, D. C., 1912. In citing specimens we have given the data received with the specimens. Wherever possible the location of the specimens has been given.

In conclusion we gratefully acknowledge all who have aided in this work. We are indebted to the Missouri Botanical Garden for the use of the library and the herbarium; to Dr. E. A. Burt and Dr. J. M. Greenman for helpful suggestions; to Dr. N. L. Gardner and Dr. W. A. Setchell for extensive collections of Hymenogastrales from California ; to Mr. C. G. Lloyd for the privileges of his herbarium; to Dr. W. A. Murrill for helpful correspondence; and to Dr. Myron R. Sanford, Middlebury College, for helpful suggestions. 


\section{$2 \mathrm{BHL}$ Biodiversity Heritage Library}

Zeller, S. M. and Dodge, Carroll W. 1919. "Arcangeliella, Gymnomyces, and Macowanites in North America." Annals of the Missouri Botanical Garden 6, 49-59. https://doi.org/10.2307/2990096.

View This Item Online: https://www.biodiversitylibrary.org/item/54261

DOI: https://doi.org/10.2307/2990096

Permalink: https://www.biodiversitylibrary.org/partpdf/10894

\section{Holding Institution}

Missouri Botanical Garden, Peter H. Raven Library

\section{Sponsored by}

Missouri Botanical Garden

\section{Copyright \& Reuse}

Copyright Status: Public domain. The BHL considers that this work is no longer under copyright protection.

This document was created from content at the Biodiversity Heritage Library, the world's largest open access digital library for biodiversity literature and archives. Visit BHL at https://www.biodiversitylibrary.org. 